\title{
Estimating Nitrogen and Chlorophyll Status of Romaine Lettuce Using SPAD and at LEAF Readings
}

\author{
Rodrigo Omar MENDOZA-TAFOLLA ${ }^{1}$, Porfirio JUAREZ-LOPEZ ${ }^{1}$, \\ Ronald-Ernesto ONTIVEROS-CAPURATA ${ }^{2 *}$, Manuel SANDOVAL- \\ VILLA $^{3}$, Iran ALIA-TEJACAL ${ }^{1}$, Gelacio ALEJO-SANTIAGO ${ }^{4}$ \\ ${ }^{1}$ Universidad Autónoma del Estado de Morelos, Posgrado en Ciencias Agropecuarias y Desarrollo Rural, Facultad de Ciencias Agropecuarias, Av. \\ Universidad 1001,62209Cuernavaca,Morelos, México; rodrigoomt@hotmail.com; porfiriojlopez@yahoo.com;iran.alia@uaem.mx \\ ${ }^{2}$ Cátedra CONACYT-Instituto Mexicano de Tecnología del Agua, Paseo Cuaubnábuac 8532, 62550 Jiutepec, Morelos, \\ México; rononti@gmail.com; reontiverosca@conacyt.mx ( ${ }^{*}$ correspondingauthor) \\ ${ }^{3}$ Colegio de Postgraduados, Edafología, Campus Montecillo 56230, Montecillo, Estado de México, México; msandoval@colpos.mx \\ ${ }^{4}$ Universidad Autónoma de Nayarit, Unidad Académica de Agricultura, Carretera Tepic-Compostela Km. 9, 63780, Xalisco, Nayarit, \\ México;gelacioalejo@hotmail.com
}

\begin{abstract}
Nitrogen $(\mathrm{N})$ is an essential nutrient for plant growth and development and is especially important in the production of high quality leafy green crops. In this experiment, leaf $\mathrm{N}$ concentration, chlorophyll concentration (Chl) and weight above fresh matter (AFM) of romaine lettuce (Lactuca sativa L. var. longifolia) were estimated by correlations between in situ SPAD and atLEAF readings. Lettuce was grown in high tunnels during 42 days and was irrigated at five nitrogen levels: $0,4,8,12$ and $16 \mathrm{mEq} \cdot \mathrm{L}^{-1}$ of $\mathrm{NO}_{3}^{-}$, with a modified Steiner nutrient solution. The $\mathrm{N}$ concentration, $\mathrm{Chl}$ concentration and AFM were determined in the laboratory, while SPAD and atLEAF readings were measured in situ weekly. SPAD readings had high, positive and significant linear correlations with $\mathrm{N}\left(\mathrm{R}^{2}=0.90\right)$, Chl $\left(\mathrm{R}^{2}=0.97\right)$ and AFM $\left(\mathrm{R}^{2}=0.98\right)$; The atLEAF readings had a similar linear correlation with $\mathrm{N}\left(\mathrm{R}^{2}=0.91\right)$, Chl $\left(\mathrm{R}^{2}=0.92\right)$ and AFM $\left(\mathrm{R}^{2}=0.97\right)$. Both, SPAD and atLEAF readings had high, positive, and significant linear correlation $\left(\mathrm{R}^{2}=0.96\right)$. Suggesting that, SPAD and atLEAF meters can be used to non-destructively and accurately estimate the $\mathrm{N}$ status of lettuce, in a reliable and quick manner during the crop production cycle.
\end{abstract}

Keywords: above fresh matter; crop nutrition; Lactuca sativa; non-destructive sampling; soilless culture

\section{Introduction}

Nitrogen $(\mathrm{N})$ is an essential nutrient for plant growth and development. It is found in amino acids, nucleic acids, proteins and in chlorophyll (Chl). The Chl concentration of the leaf is closely related to $\mathrm{N}$ concentration in the plant (Zebarth et al., 2002), therefore, monitoring plant Chl and $\mathrm{N}$ concentrations during production could be used as a management strategy to enhance plant growth, yield and marketability (Gitelson et al., 2003; Peng and Yuan, 2017).

Current destructive methods for the determination of $\mathrm{N}$ and $\mathrm{Chl}$ are precise, but time-consuming and relatively expensive (Kalaji et al., 2017). In contrast, portable nondestructive equipment has been used successfully with some plant species to quickly estimate the leaf Chl or $\mathrm{N}$ concentrations in situ (Loh et al., 2002; Abdelhamidg et al., 2003; Padilla et al., 2018a) and enable repeat measurements from the same leaf during a production cycle (Kalaji et al., 2017; Yamamoto et al., 2002).

The SPAD 502 Plus Chlorophyll Meter (Konica Minolta ${ }^{\oplus}$ Japan) is used for rapid and non-destructive determination of relative leaf $\mathrm{Chl}$ concentration (Gianquinto et al., 2004). Transmission of light through the leaf is measured at 650 and $940 \mathrm{~nm}$; the wavelength of 650 $\mathrm{nm}$ coincides with the spectral region with maximum chlorophyll activity, while transmittance at $940 \mathrm{~nm}$ is used to compensate for factors, including leaf moisture content and thickness (Zhu et al., 2012). It has been reported that the SPAD readings are related to the concentration of foliar 
752

chlorophyll (Uddling et al., 2007; Basyouni et al., 2015; Basyouni and Dunn, 2017).

The atLEAF CHL chlorophyll meter (FT Green LLC', USA) works in a similar way to the SPAD meter, but uses a wavelength of $660 \mathrm{~nm}$ instead of $650 \mathrm{~nm}$ (Zhu et al., 2012). Readings obtained with an atLEAF CHL PLUS chlorophyll meter are similar to those obtained with the SPAD meter (Basyouni et al., 2015), but the atLEAF meter is currently more affordable when compared to the SPAD meter (Zhu et al., 2012; Basyouni and Dunn, 2017).

It has been reported that the $\mathrm{Chl}$ and $\mathrm{N}$ concentrations determined in the laboratory have high correlations with the SPAD readings for a variety of plant species, including: corn (Hurtado et al., 2010), tomato (Ferreira et al., 2006), cabbage (Westerveld et al., 2003), rice (Huang et al., 2016) and mangrove (Dou et al., 2018). High correlations have also been reported with atLEAF meter in corn, wheat (Zhu et al., 2012) and sage (Dunn et al., 2018a).

Padilla et al. (2018b) have reported relatively lower sensitivity of the atLEAF meter in sweet pepper, but it was suggested that there was limited literature available for the atLEAF and that in general, there is limited researchfocused on vegetable crops when compared to cereal crops like wheat or maize (Padilla et al., 2018a).

Lettuce is the most important crop in the group of leafy vegetables around the world, due its high nutritive value and because it is a source of many vitamins and contains minerals (Noumedem et al., 2017). In 2017, worldwide production of lettuce was 26.9 million tons (Food and Agriculture Organization of the United Nations, 1998) with China leading production with 15.2 million tons. Mexico ranks tenth globally for lettuce production with 480,808 tons produced (SIAP, 2019) and fourth globally for lettuce exports, with an estimated value of 268 million dollars (OEC, 2019).

The objectives of this study were to estimate leaf $\mathrm{N}$ concentration, chlorophyll concentration (Chl) and weight above-ground fresh matter (AFM) of romaine lettuce using SPAD and atLEAF readings.

\section{Materials and Methods}

\section{Cultural conditions}

This study was conducted in high tunnels, at the Faculty of Agricultural Sciences Autonomous University of the State of Morelos, Chamilpa, Cuernavaca, Morelos, Mexico $\left(18^{\circ} 58^{\prime} 51^{\prime \prime} \mathrm{N}, 99^{\circ} 13^{\prime} 55^{\prime \prime} \mathrm{W}\right.$, altitude of 1,866 m.a.s.l.), from April to May of 2018. Temperature, relative humidity, and light intensity were recorded hourly from $\mathrm{Hobo}^{\circ}$ datalogger U12-012 (Onset Computer Co., USA) for the duration of the experiment. The maximum and minimum temperatures were $40{ }^{\circ} \mathrm{C}$ and $13{ }^{\circ} \mathrm{C}$, respectively, with an average of $26^{\circ} \mathrm{C}$. The maximum and minimum relative humidity was $83 \%$ and $15 \%$, respectively, with an average of $45 \%$. Average light intensity for the duration of the experiment was 28,000 lux.
Seeds of romaine lettuce 'Green Star' (Johnny's Seeds, USA) were sown (March 13, 2018) into 200-well polystyrene trays $(30 \mathrm{~mL})$, previously filled with $\mathrm{BM} 2$ Berger commercial substrate and were transplanted (April 13,2018 ) into $10 \mathrm{~L}$ polyethylene bags, which had been filled with volcanic rock (locally called tezontle) with a granulometry of 1 to $7 \mathrm{~mm}$.

Lettuce seedlings were irrigated daily with approximately $0.5 \mathrm{~L}$ of Steiner's nutrient solution, modified to provide nitrate at $0,4,8,12$ and $16 \mathrm{mEq} \cdot \mathrm{L}^{-1}$ (MercadoLuna et al., 2010) for the first three weeks, and then with $1.5 \mathrm{~L}$ of nutrient solution for the remaining period of the study (42 Days After Transplanting). Plants were irrigated to achieve approximately $20 \%$ leaching fraction by volume. Micronutrients were added as a commercial mixture of chelates (Microsol Rexene Mix SQM) in doses of $80 \mathrm{~g} \mathrm{~m}^{-3}$, to achieve a supply of $3 \mathrm{mg} \cdot \mathrm{L}^{-1}$ of iron. The $\mathrm{pH}$ of the nutrient solutions was acidified with sulfuric acid to values between 5.6 and 6.0.

\section{Measurements and observations}

In situ sampling using the SPAD-502 Plus Minolta and atLEAF ${ }^{\circ} \mathrm{CHL}$ Plus portable meters (Fig. 1) was conducted weekly at approximately solar noon as described by León $e t$ al. (2017). Briefly, SPAD and atLEAF value were obtained from six plants per treatment, with ten readings per leaf (five on each side of the leaf midrib), from three fully expanded, recently matured leaves per plant. Immediately after finishing the measurements in situ, the fresh aerial biomass of the plants was harvested to determine the AFM with an OHAUS lab balance.

The same leaves used in SPAD and atLEAF measurements were then immediately sampled to determine Chl concentration (mg.g ${ }^{-1}$ as described by Mackinney (1941) and von Wettstein (1957). Briefly, a portion of fresh biomass $(1 \mathrm{~g})$ was harvested from the plant, homogenized with $20 \mathrm{~mL}$ of concentrated acetone, filtered and adjusted to $50 \mathrm{~mL}$ of $80 \%$ acetone. Leaf samples and suspensions were kept in the dark between the processing steps. Absorbance $(A)$ readings were taken at $645 \mathrm{~nm}$ and $663 \mathrm{~nm}$ on a UV-Vis Spectrophotometer DR 5000 ( $\mathrm{HACH}$, Canada). The calculations were made with the following equation:

\section{Total Chl $=\left(20.2 \times \mathrm{A}_{645 \mathrm{~nm}}\right)+\left(8.02 \times \mathrm{A}_{663 \mathrm{~mm}}\right)$}

Samples were then dried in a forced air oven at $70{ }^{\circ} \mathrm{C}$ for 72 hours and then ground. Total $\mathrm{N}$ was quantified by the micro Kjeldahl method as described by Kalra (1997).

\section{Design and statistical analysis}

A completely randomized experimental design was used, at five nitrogen levels $\left(0,4,8,12\right.$ and $16 \mathrm{mEq} \cdot \mathrm{L}^{-1}$ of $\left.\mathrm{NO}_{3}^{-}\right)$, with six plants per treatment. There was one plant per container, with each container as a single replication (Fig. 2). Correlations were made of the SPAD and atLEAF readings against $\mathrm{N}$ concentration, $\mathrm{Chl}$ concentration and AFM using SigmaPlot ${ }^{\circ}$ Ver. 12.5 (SYSTAT Inc., USA). 

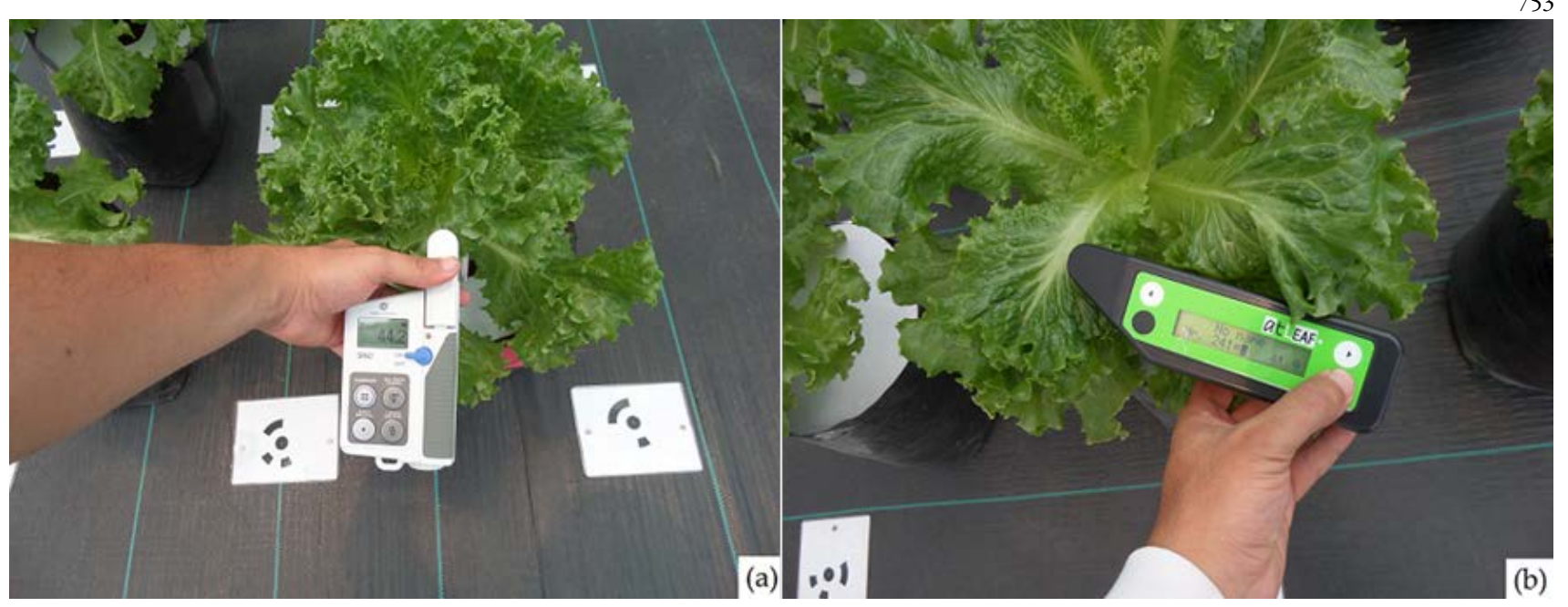

Fig. 1. Use of SPAD (a) and atLEAF (b) to measure relative chlorophyll concentration in romaine lettuce
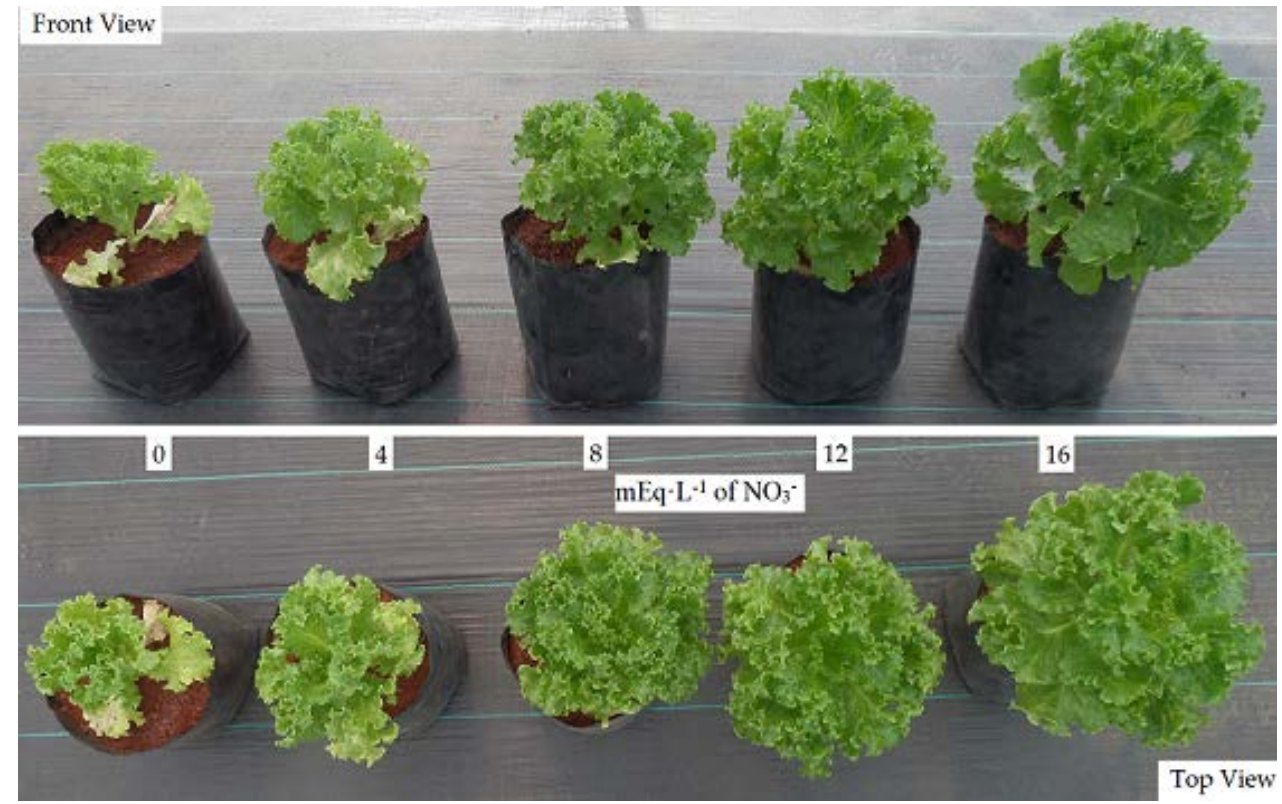

Fig. 2. Front view and top view of romaine lettuce growth as a function of $\mathrm{N}-\mathrm{NO}_{3}$ level at harvest

\section{Results and Discussion}

Relationship between $N$ concentration, SPAD and atLEAF readings

SPAD readings had a high correlation $(\alpha=0.01)$ with leaf $\mathrm{N}$ concentration in romaine lettuce. The simple linear regression (Fig. 3) has a positive correlation coefficient ( $\mathrm{r}$ ) of 0.95 , a coefficient of determination $\left(\mathrm{R}^{2}\right)$ of 0.90 and a RMSE of 0.02. These values were higher than those reported in other plant species, for example oregano $(\mathrm{r}=$ 0.80, $\mathrm{R}^{2}=0.64$ ) (Calderón-Medellín et al., 2011) for correlation of SPAD and leaf $\mathrm{N}$ concentration. The results of the present study suggest that SPAD is a reliable instrument for estimating the concentration of $\mathrm{N}$ in lettuce plants, as reported for basil (Ruiz-Espinoza et al., 2010), spinach (Liu et al., 2006) and poinsettia (Dunn et al., 2018b).

$\mathrm{N}$ concentration and atLEAF readings show a high linear correlation coefficient $\left(r=0.96, \mathrm{R}^{2}=0.91\right.$, RMSE = 0.02, $\alpha=0.01$ ) (Fig. 3), which indicates that the atLEAF meter can be used for reliable and rapid estimation of $\mathrm{N}$ concentration in romaine lettuce plants. These results are similar to the studies carried out by Zhu et al. (2012) who reported that the atLEAF meter could be an affordable and reliable alternative $\left(\mathrm{R}^{2}=0.78-0.92\right)$ for the estimation of $\mathrm{N}$ concentration in corn, wheat, barley, potato and canola. Similarly, Basyouni et al. (2015) reported high correlation values $\left(\mathrm{R}^{2}=0.75-0.83\right)$ between $\mathrm{N}$ concentration and atLEAF readings when evaluating induced $\mathrm{N}$ deficiencies in two varieties of poinsettia.

\section{Relationship between Chl concentration, SPAD and} at $L E A F$ readings

The correlation between SPAD readings and the Chl concentration (Fig. 4) was highly significant and positive $(\mathrm{r}$ $\left.=0.99, \mathrm{R}^{2}=0.97, \mathrm{RMSE}=0.03, \alpha=0.01\right)$, which are similar to those of Fenech-Larios et al. (2009) who found high correlation of SPAD readings and Chl concentration $(r=0.99)$ in basil seedlings. The correlations of our present study are stronger than those reported by Martín et al. 
754

(2007) who in viburnum, pittosporum and arbutus, and Ruiz-Espinoza et al. (2010) in basil found correlation coefficients between 0.36 and 0.52 , and 0.57 , and 0.67 , respectively.

Chl concentration and atLEAF readings had a high linear correlation $\left(r=0.96, \mathrm{R}^{2}=0.92, \mathrm{RMSE}=0.09, \alpha=\right.$ $0.01)$. In that, our results had a higher adjustment when compared to those described by Zhu et al. (2012) who reported coefficients of determination between 0.72-0.88 for Chl concentration and atLEAF readings in corn, wheat, barley, potato and canola. While, Hebbar et al. (2016) reported coefficients of correlation between 0.68-0.95 in coconut palm leaves.

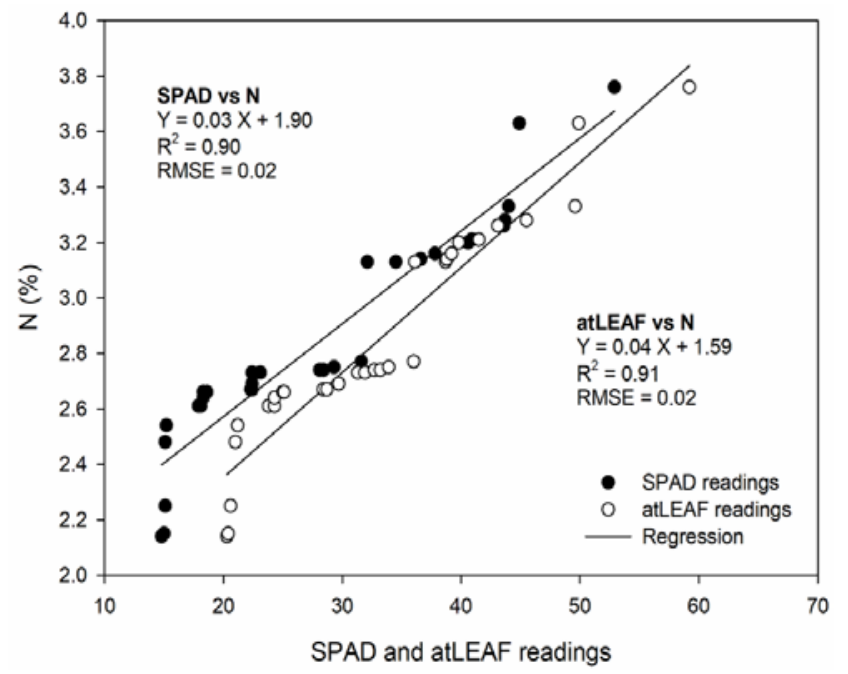

Fig. 3. Relationship between $\mathrm{N}$ concentration, SPAD and atLEAF readings in romaine lettuce

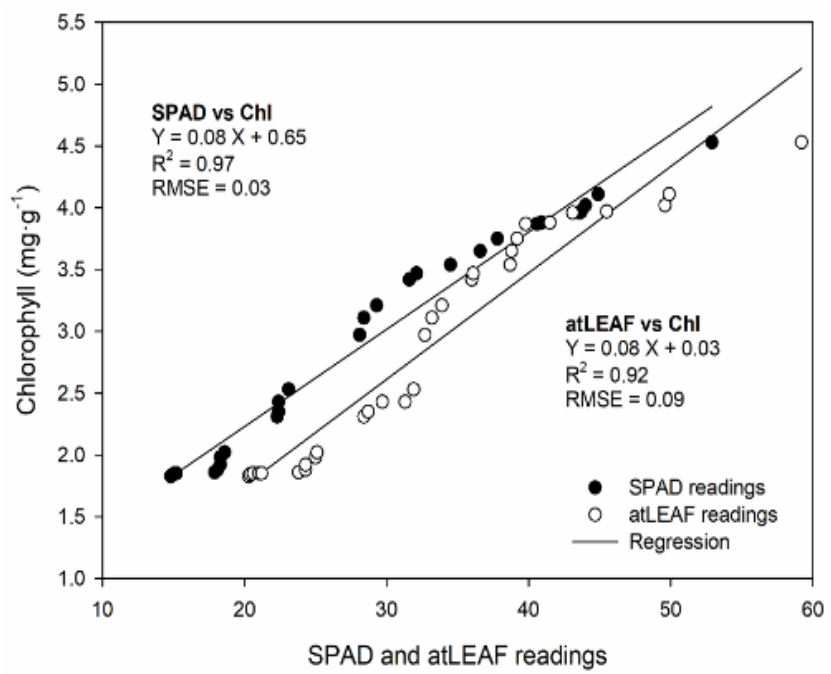

Fig. 4. Relationship between $\mathrm{Chl}$ concentration, SPAD and atLEAF readings in romaine lettuce
Relationship between AFM, SP AD and at $L E A F$ readings

SPAD readings had a high correlation $(\alpha=0.01)$ with AFM in romaine lettuce. The simple linear regression (Fig. 5) shows a positive correlation coefficient ( $r$ ) of 0.99 and a coefficient of determination $\left(\mathrm{R}^{2}\right)$ of 0.98 . These results are similar to those reported by Cunha et al. (2015) with correlation coefficients between 0.92-0.98 in arugula. Also, Cho et al. (2007) suggested that the SPAD readings could be used in the field to estimate and project growth rates and predict yields in the cucumber crop. Therefore, SPAD can be considered as a tool to quickly and reliably estimate the AFM in lettuce.

Correlation between the atLEAF readings and AFM (Fig. 5) was highly significant $(\alpha=0.01)$ and presented a 'good fit' to the linear regression $\left(r=0.98, R^{2}=0.97\right.$, RMSE $=0.04)$. These results are similar to those reported by Dey et al. (2016) who obtained values of $r=0.97$ and $R^{2}=0.95$ in betel vine.

AFM in lettuce is important because it is closely related to the yield of this crop. According to our results, the use of both SPAD and atLEAF meters could be used as a tool to predict potential yield.

\section{Correlation between SPAD and at $L E A F$ readings}

SPAD and atLEAF readings show a high linear correlation coefficient $\left(r=0.98, R^{2}=0.96\right.$, RMSE $=0.06, \alpha$ $=0.01$ ) (Fig. 6). These results are similar to those reported by Dunn et al. (2018b) who obtained a correlation coefficient of 0.80 to 0.95 between the SPAD and atLEAF readings in poinsettia leaves. Zhu et al. (2012) found significant correlations between the SPAD and atLEAF readings for corn, barley and potato $\left(\mathrm{R}^{2}=0.90-0.92\right)$. Both of these studies concluded that the atLEAF meter represented a cheaper alternative to the SPAD meter.

AtLEAF meter may be preferable as it is more affordable and is $80 \%$ cheaper than SPAD meter. However, it is important to mention that the readings of SPAD and atLEAF in leaves may not be representative of the entire plant canopy and should therefor viewed with a certain amount of caution.

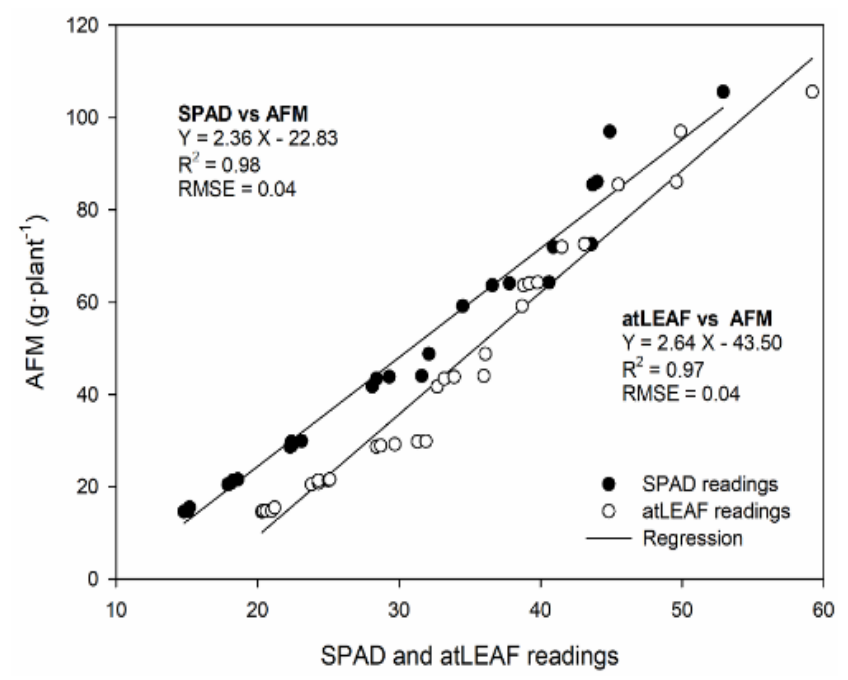

Fig. 5. Relationship between AFM, SPAD and atLEAF readings in romaine lettuce 


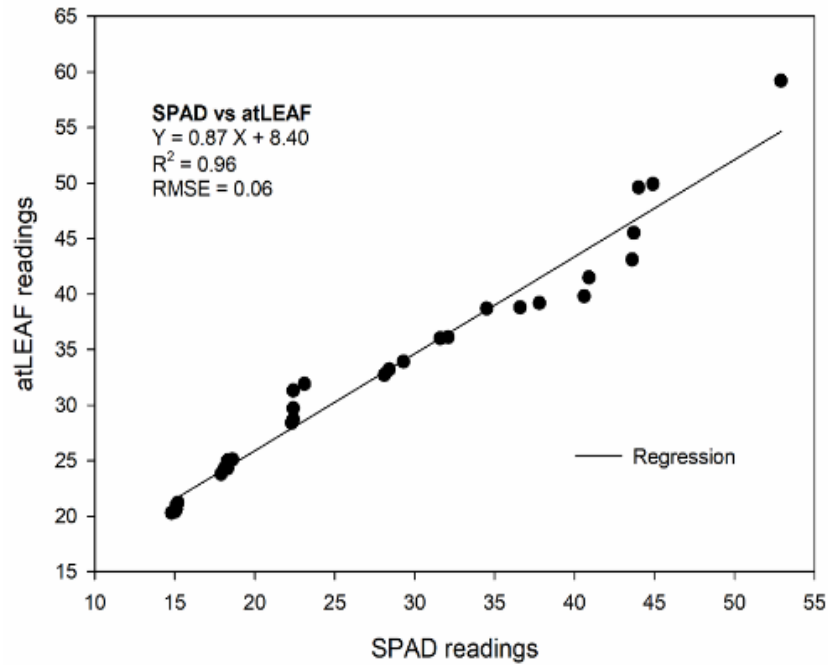

Fig. 6. Correlation between SPAD and atLEAF readings in romaine lettuce

\section{Conclusions}

This study shows that both meters (SPAD and atLEAF) accurately predict leaf $\mathrm{N}$ and $\mathrm{Chl}$ concentrations and AFM in romaine lettuce from linear regression equations. SPAD readings had high, positive and significant linear correlations with $\mathrm{N}\left(\mathrm{R}^{2}=0.90\right)$, Chl concentration $\left(\mathrm{R}^{2}=\right.$ $0.97)$ and AFM $\left(R^{2}=0.98\right)$, AtLEAF readings had a similar linear correlation with $\mathrm{N}\left(\mathrm{R}^{2}=0.91\right)$, Chl concentration $\left(\mathrm{R}^{2}=0.92\right)$ and AFM $\left(\mathrm{R}^{2}=0.97\right)$. Both the SPAD and atLEAF readings allow for early estimates of plant nitrogen and chlorophyll status that can be used to schedule fertilizer application more efficiently during the growing season without affecting the development of the plants. The relationship between SPAD and atLEAF readings was also high, positive, and had a significant linear correlation $\left(\mathrm{R}^{2}=\right.$ 0.96). Both SPAD and atLEAF meters can be used to nondestructively and accurately estimate the $\mathrm{N}$ status of lettuce, in a reliable and quick manner during the crop production cycle. In addition, atLEAF meter is currently more affordable than SPAD meter.

\section{Acknowledgment}

The first author is grateful to the National Council for Science and Technology (CONACYT-Mexico) for the scholarship number 473176 awarded for Graduate Studies. Also, the authors thank to Dr. Andrew Cartmill for the English language support.

\section{References}

Abdelhamidg M, Horiuchi T, ObaS (2003). Evaluation of the SPAD value in Faba bean (Vicia faba L.) leaves in relation to different fertilizer applications. Plant Production Science 6(3):185-189.

Basyouni R, Dunn B (2017). Use of reflectance sensors to monitor plant nitrogen status in horticultural plants. Retrieved 2019 March 2 from http://factsheets.okstate.edu/documents/hla-6719-use-of-opticalsensors-to-monitor-plant-nitrogen-status-in-horticultural-plants/.
Basyouni R, Dunn BL, Goad C (2015). Use of nondestructive sensors to assess nitrogen status in potted poinsettia (Euphorbia pulcherrima L. (Willd. ex Klotzsch)) production. Scientia Horticulturae 192:47-53.

Calderón-Medellín LA, Bernal-Rozo AM, Pérez-Trujillo MM (2011). Ensayo preliminar sobre la utilización de un medidor portátil de clorofila para estimar el nitrógeno foliar en orégano (Origanum vulgare L.). Revista Facultadde Ciencias Básicas 7(2):150-165.

Cho YY, Oh S, Oh MM, Son JE (2007). Estimation of individual leaf area, fresh weight, and dry weight of hydroponically grown cucumbers (Cucumis sativus $\mathrm{L}$.) using leaf length, width, and SPAD value. Scientia Horticulturae 111(4):330-334.

Cunha ARd, Katz I, Sousa ADP, Martinez RA (2015). Índice SPAD en el crecimiento y desarrollo de plantas de lisianthus en función de diferentes dosis de nitrógeno en ambiente protegido. Idesia (Arica) 33:97-105.

Dey AK, Sharma M, Meshram MR (2016). An analysis of leaf chlorophyll measurement method using chlorophyll meter and image processing technique.Procedia Computer Science 85:286-292.

Dou Z, Cui L, Li J, Zhu Y, Gao C, Pan X, ... Li W (2018). Hyperspectral estimation of the chlorophyll content in short-term and long-term restorations of mangrove in Quanzhou Bay Estuary, China. Sustainability 10(4):1127.

Dunn BL, Singh H, Payton M, Kincheloe S (2018a). Effects of nitrogen, phosphorus, and potassium on SPAD-502 and atLEAF sensor readings ofSalvia Journal of Plant Nutrition 41(13):16741683.

Dunn BL, Singh H, Goad C (2018b). Relationship between chlorophyll meter readings and nitrogen in poinsettia leaves. Journal of Plant Nutrition 41(12):1566-1575.

Fenech-Larios L, Troyo-Diéguez E, Trasviña-Castro M, Ruiz-Espinoza F, Beltrán-Morales A, Murillo-Amador B, ... Zamora-Salgado S (2009). Relación entre un método no destructivo y uno de extracción destructivo, para medir el contenido de clorofila en hojas de plántula de albahaca (Ocimum basilicum L). Universidad y Ciencia 25(1):99-102.

Ferreira M, Ferreira G, Fontes P, Dantas J (2006). Índice SPAD e teor de clorofila no limbo foliar do tomateiro em função de doses de nitrogênioe da adubação orgânica, em duas épocas de cultivo. Revista Ceres 53:8392.

Food and Agriculture Organization of the United Nations. (1998). FAOSTAT statistics database. Retrieved 2019 March 02 from: https://search.library.wisc.edu/catalog/999882363002121.

Gianquinto G, GoffartJP, Olivier M, Guarda G, Colauzzi M, Dalla Costa L, ... Mackerron DKL (2004). The use of hand-held chlorophyll meters as a tool to assess the nitrogen status and to guide nitrogen fertilization of potato crop. Potato Research 47(1-2):35-80.

Gitelson AA, Gritz Y, Merzlyak MN (2003). Relationships between leaf chlorophyll content and spectral reflectance and algorithms for nondestructive chlorophyll assessment in higher plant leaves. Journal of Plant Physiology 160(3):271-282.

Hebbar KB, Subramanian P, Sheena TL, Shwetha K, Sugatha P, Arivalagan M, Varaprasad PV (2016). Chlorophyll and nitrogen determination in coconut using a non-destructive method. Journal of Plant Nutrition 39(11):1610-1619.

Huang L, Yang J, Cui X, Yang H, Wang S, Zhuang H (2016). Synergy and transition of recovery efficiency of nitrogen fertilizer in various rice genotypes under organic farming. Sustainability 8(9):854. 
756

Hurtado SMC, Silva CA, Resende ÁVd, Corazza EJ, Shiratsuchi LS, Higashikawa FS (2010). Sensibilidade do clorofilômetro para diagnóstico nutricional de nitrogênio no milho. Ciência e Agrotecnologia 34:688-697.

Kalaji HM, Dąbrowski P, Cetner MD, Samborska IA, Łukasik I, Brestic M, ... Panchal BM (2017). A comparison between different chlorophyll content meters under nutrient deficiency conditions. Journal of Plant Nutrition 40(7):1024-1034.

Kalra Y (1997). Handbook of reference methods for plant analysis. CRC press, Boca Raton.

León AP, Viña SZ, Frezza D, Chaves A, Chiesa A (2007). Estimation of chlorophyll contents by correlations between SPAD-502 meter and chroma meter in butterhead lettuce. Communications in Soil Science and Plant Analysis 38(19-20):2877-2885.

Liu YJ, Tong YP, Zhu YG, Ding H, Smith FA (2006). Leaf chlorophyll readings as an indicator for spinach yield and nutritional quality with different nitrogen fertilizer applications. Journal of Plant Nutrition 29(7):1207-1217.

Loh FCW, GraboskyJC, Bassuk NL (2002). Using the SPAD 502 meter to assess chlorophyll and nitrogen content of Benjamin fig and cottonwood leaves. HortTechnology 12(4):682-686.

Lucini L, Rouphael Y, Cardarelli M, Canaguier R, Kumar P, Colla G(2015). The effect of a plant-derived biostimulant on metabolic profiling and crop performance of lettuce grown under saline conditions. Scientia Horticulturae 182:124-133.

Mackinney G (1941). Absorption of light by chlorophyll solutions. Journal of Biological Chemistry 140(2):315-322.

Martín I, Alonso N, López MC, Prieto M, Cadahía C, Eymar E. (2007). Estimation of leaf, root, and sap nitrogen status using the SPAD-502 chlorophyll meter for ornamental shrubs. Communications in Soil Science and Plant Analysis 38(13-14):1785-1803.

Mercado-Luna A, Rico-García E, Lara-Herrera A, Soto-Zarazúa G, Ocampo-Velázquez R, Guevara-González R, ... Torres-Pacheco I (2010). Nitrogen determination on tomato (Lycopersicon esculentum Mill.) seedlings by color image analysis (RGB). African Journal of Biotechnology 9(33):5326-5332.

Noumedem JAK, Djeussi DE, Hritcu L, Mihasan M, Kuete V (2017). Chapter 20 - Lactuca sativa. In: Kuete V (Ed). Medicinal spices and vegetables from Africa. Academic Press, London, pp 437449.

Padilla F, Gallardo M, Peña-Fleitas M, de Souza R, Thompson R (2018a). Proximal optical sensors for nitrogen management of vegetable crops: a review.Sensors 18(7).
Padilla F, de Souza R, Peña-Fleitas MT, Gallardo M, Giménez C, Thompson RB (2018b). Different responses of various chlorophyll meters to increasing nitrogen supply in sweet pepper. Frontiers in Plant Science 9:1752.

Parks SE, Irving DE, Milham PJ (2012). A critical evaluation of on-farm rapid tests for measuring nitrate in leafy vegetables. Scientia Horticulturae 134:1-6.

Peng S, Yuan S (2017). Exploring the trends in nitrogen input and nitrogen use efficiency for agricultural sustainability. Sustainability 9(10):1905.

Ruiz-Espinoza FH, Murillo-Amador B, García-Hernández JL, FenechLarios L, Rueda-Puente EO, Troyo-Diéguez E, . . . Beltrán-Morales A (2010). Field evaluation of the relationship between chlorophyll content in basil leaves and a portable chlorophyll meter (SPAD-502) readings. Journal of Plant Nutrition 33(3):423-438.

SIAP (2019). Servicio de Información Agroalimentaria y Pesquera. Retrieved 2019March 02 from https://www.gob.mx/siap.

OEC (2019). The Observatory of Economic Complexity. Lechuga. Retrieved 2019 March 02 from https://atlas.media.mitEdu/es/profile/hs92/0705/.

Uddling J, Gelang-Alfredsson J, Piikki K, Pleijel H (2007). Evaluating the relationship between leaf chlorophyll concentration and SPAD-502 chlorophyll meter readings. Photosynthesis Research 91(1):37-46.

von Wettstein D (1957). Chlorophyll-letale und der submikroskopische Formwechsel der Plastiden. Experimental Cell Research 12(3):427-506.

Westerveld SM, McKeown AW, McDonald MR, Scott-Dupree CD (2003). Chlorophyll and nitrate meters as nitrogen monitoring tools for selected vegetables in southern Ontario. Acta Horticulturae 627:259266.

Yamamoto A, Nakamura T, Adu-Gyamfi JJ, Saigusa M (2002). Relation between chlorophyll content in leaves of sorghum and pigeonpea determined by extraction method and by chlorophyll meter (SPAD502). Journal of Plant Nutrition 25(10):2295-2301.

Zebarth BJ, Younie M, Paul JW, Bittman S (2002). Evaluation of leaf chlorophyll index for making fertilizer nitrogen recommendations for silage corn in a high fertility environment. Communications in Soil Science and Plant Analysis 33(5-6):665-684.

Zhu J, Tremblay N, Liang Y (2012). Comparing SPAD and atLEAF values for chlorophyll assessment in crop species. Canadian Journal of Soil Science 92(4):645-648. 